\title{
Are There Differences in Female Sexuality Related to Educational Level?
}

\author{
http://bjas.journals.ekb.eg
}

\author{
I.Y.Abdallah, H.M.ElHadi and S. I.Younis.
}

Dermatology, Venereology and AndrologyDept., Faculty of Medicine, Benha Univ., Benha, Egypt

E-Mail: drsamahyounes@gmail.com

\begin{abstract}
Sexual knowledge is a collection of information and refers to the knowledge and awareness of the individual about sex and sexuality (including physiological aspects, reproduction, performance, and individual sexual behavior). Absence of sexual information is related with an expansion in powerlessness, which makes a setting for the rise of sexual issue. Training not just has a constructive job in anticipation of adverse results, for example, explicitly transmitted contaminations ,sexual maltreatment and sexual discouragement, yet in addition prompts constructive results at individual levels and relational relationships.evaluate the effect of various instructive levels on female sexuality in an example of Egyptian wedded women.a self-report survey planned by the creators guided by the female sexual capacity index[1].The point of the investigation and the subtleties of the poll were disclosed to the ladies before taking their educated assent. Members were 300 hitched ladies going to the outpatient center in Benha University emergency clinic, Maternal and Childhood care units in Benha city, during the period from October 2019 to May 2020.They were educated about the idea of the investigation and requested to partake before taking their educated consent.increasing in level of training prompts progressively sexual satisfaction.The present examination discoveries show that Increase in the degree of instruction prompts expanded sexual movement (want, grease, sexual fulfillment) and to increasingly sexual fulfillment. Sexual information and experience increments with expanding level of training. Ladies with elevated level of training can manage any issue identified with sexuality so female sexual dysfunctions are less in profoundly taught women.Educational level and sexual fulfillment were fundamentally related.
\end{abstract}

Keywords: Educational level,Female sexual satisfaction, Female sexual function .

\section{Introduction}

Fulfilling sex is a basic component for by and large wellbeing and joy for some people, as sexuality assumes a significant job in close connections and is a significant part of generally speaking passionate and physical wellbeing [2]. Sexual fulfillment or in another word the fulfillment of that individual's sex guarantee, is a significant marker of an effective marriage which results the endurance and wellbeing of the family [3]. Individuals who have a level of sexual fulfillment have significantly preferable personal satisfaction over the individuals who revealed no sexual fulfillment [4]. Training represents assurance, introduction expansion, improvement and advancement of the family dependent on acknowledged moral thoughts [5]. Instruction not just has a constructive job in anticipation of contrary results, for example, explicitly transmitted contaminations, sexual maltreatment and sexual sadness, yet additionally prompts constructive results at individual levels and relational connections [6]. Taught ladies can be a decent wellspring of data move to their spouses, youngsters and friends [7].

\section{Material and methods}

Table (1) Data of level of education $(n=300)$.
The current examination is a cross sectional investigation. The subjects of this investigation were hitched ladies of various ages and levels of instruction.

In the wake of taking the endorsement of the Ethical Committee and Dermatology and Andrology office in Benha University, the investigation continued as follows: the instrument of the examination was a self-report survey planned by the creators guided by the female sexual capacity list [1].

The point of the investigation and the subtleties of the poll were disclosed to the ladies before taking their educated assent.

Members were 300 hitched ladies going to the outpatient center in Benha University emergency clinic, Maternal and Childhood care units in Benha city, during the period from October 2019 to May 2020.

\section{Statistical analysis}

Data were fed to the computer and analyzed using IBM SPSS software package version 20.0. (Armonk, NY: IBM Corp) Qualitative data were described using number and percent. Significance of the obtained results was judged at the $5 \%$ level.

\section{Results and discussion}

\begin{tabular}{lcc}
\hline Variable & \multicolumn{2}{c}{ Studied group } \\
\cline { 2 - 3 } & \multicolumn{2}{c}{$(\mathbf{n = 3 0 0 )}$} \\
\cline { 2 - 3 } & $\mathbf{n}$ & \% \\
\hline Illiterate & 26 & 8.7 \\
Can only read and write & 18 & 6.0 \\
Secondary education & 99 & 33.0 \\
University student & 26 & 8.7 \\
University degree & 89 & 29.7 \\
MSc or MD & 42 & 14.0 \\
\hline
\end{tabular}

Table (2)Relation between level of education and some sexual functions $(n=300)$. 


\begin{tabular}{|c|c|c|c|c|c|c|c|c|c|c|c|c|c|c|c|}
\hline & & \multicolumn{2}{|c|}{ Illiterate } & \multicolumn{2}{|c|}{$\begin{array}{c}\text { Read and } \\
\text { write }\end{array}$} & \multicolumn{2}{|c|}{$\begin{array}{c}\text { Secondary } \\
\text { education }\end{array}$} & \multicolumn{2}{|c|}{$\begin{array}{c}\text { University } \\
\text { student }\end{array}$} & \multicolumn{2}{|c|}{$\begin{array}{c}\text { University } \\
\text { degree }\end{array}$} & \multicolumn{2}{|c|}{$\begin{array}{c}\text { MSC or } \\
\text { MD }\end{array}$} & \multirow{2}{*}{$\begin{array}{c}\begin{array}{c}\text { Statistic } \\
\text { al test }\end{array} \\
\mathbf{X}^{2} \text { test }\end{array}$} & \multirow[t]{2}{*}{$\begin{array}{c}\mathbf{P} \\
\text { value }\end{array}$} \\
\hline & & $\mathbf{N}$ & $\%$ & $\mathbf{n}$ & $\%$ & $\mathbf{N}$ & $\%$ & $n$ & $\%$ & $\mathbf{n}$ & $\%$ & $\mathbf{n}$ & $\%$ & & \\
\hline \multirow{5}{*}{$\begin{array}{l}\text { Frequency of } \\
\text { sexual } \\
\text { intercourse }\end{array}$} & Daily & 0 & 0.0 & 0 & 0.0 & 3 & 3.0 & 1 & 3.8 & 4 & 4.5 & 2 & 4.8 & 31.437 & ${ }^{\mathrm{MC}} \mathrm{p}=$ \\
\hline & $\begin{array}{l}\text { 2-3 times a } \\
\text { week }\end{array}$ & 11 & 42.3 & 8 & 44.4 & 45 & 45.5 & 16 & 61.5 & 58 & 65.2 & 29 & 69.0 & & $0.017^{*}$ \\
\hline & Once a week & 9 & 34.6 & 6 & 33.3 & 30 & 30.3 & 7 & 26.9 & 24 & 27.0 & 11 & 26.2 & & \\
\hline & Once a month & 3 & 11.5 & 2 & 11.1 & 11 & 11.1 & 1 & 3.8 & 2 & 2.2 & 0 & 0.0 & & \\
\hline & Less than that & 3 & 11.5 & 2 & 11.1 & 10 & 10.1 & 1 & 3.8 & 1 & 1.1 & 0 & 0.0 & & \\
\hline \multirow[t]{6}{*}{$\begin{array}{l}\text { Thoughts and } \\
\text { fantasies }\end{array}$} & $\begin{array}{l}\text { More than } \\
\text { once per day }\end{array}$ & 0 & 0.0 & 0 & 0.0 & 2 & 2.0 & 2 & 7.7 & 2 & 2.2 & 0 & 0.0 & 73.396 & ${ }_{<0.001^{*}}^{\mathrm{MC}_{\mathrm{p}}}$ \\
\hline & Once daily & 2 & 7.7 & 2 & 11.1 & 14 & 14.1 & 4 & 15.4 & 14 & 15.7 & 7 & 16.7 & & \\
\hline & $\begin{array}{l}\text { 2-3 times a } \\
\text { week }\end{array}$ & 4 & 15.4 & 3 & 16.7 & 17 & 17.2 & 10 & 38.5 & 37 & 41.6 & 20 & 47.6 & & \\
\hline & Once a week & 6 & 23.1 & 5 & 27.8 & 29 & 29.3 & 8 & 30.8 & 30 & 33.7 & 15 & 35.7 & & \\
\hline & Once a month & 5 & 19.2 & 3 & 16.7 & 15 & 15.2 & 1 & 3.8 & 4 & 4.5 & 0 & 0.0 & & \\
\hline & Less than that & 9 & 34.6 & 5 & 27.8 & 22 & 22.2 & 1 & 3.8 & 2 & 2.2 & 0 & 0.0 & & \\
\hline \multirow[t]{4}{*}{ Lubrication } & Always & 4 & 15.4 & 3 & 16.7 & 34 & 34.3 & 13 & 50.0 & 52 & 58.4 & 29 & 69.0 & 57.931 & ${ }^{\mathrm{MC}} \mathrm{p}$ \\
\hline & $\begin{array}{l}\text { About half the } \\
\text { times }\end{array}$ & 5 & 19.2 & 4 & 22.2 & 22 & 22.2 & 6 & 23.1 & 22 & 24.7 & 11 & 26.2 & & $<0.001^{*}$ \\
\hline & $<$ half times & 6 & 23.1 & 4 & 22.2 & 13 & 13.1 & 3 & 11.5 & 5 & 5.6 & 1 & 2.4 & & \\
\hline & $\begin{array}{l}\text { Rare or almost } \\
\text { never }\end{array}$ & 11 & 42.3 & 7 & 38.9 & 30 & 30.3 & 4 & 15.4 & 10 & 11.2 & 1 & 2.4 & & \\
\hline \multirow{4}{*}{$\begin{array}{l}\text { Response to } \\
\text { husband request } \\
\text { to establish sexual } \\
\text { relationship }\end{array}$} & $\begin{array}{l}\text { Always } \\
\text { approve }\end{array}$ & 8 & 30.8 & 3 & 16.7 & 28 & 28.3 & 12 & 46.2 & 26 & 29.2 & 17 & 40.5 & 35.650 & $0.002^{*}$ \\
\hline & $>$ half times & 5 & 19.2 & 6 & 33.3 & 23 & 23.2 & 4 & 15.4 & 31 & 34.8 & 23 & 54.8 & & \\
\hline & $<$ half times & 5 & 19.2 & 4 & 22.2 & 21 & 21.2 & 3 & 11.5 & 14 & 15.7 & 1 & 2.4 & & \\
\hline & $\begin{array}{l}\text { Disapproval } \\
\text { every time }\end{array}$ & 8 & 30.8 & 5 & 27.8 & 27 & 27.3 & 7 & 26.9 & 18 & 20.2 & 1 & 2.4 & & \\
\hline \multirow{4}{*}{$\begin{array}{l}\text { The reason for } \\
\text { accepting the } \\
\text { husband desire to } \\
\text { establish sexual } \\
\text { relationship }\end{array}$} & $\begin{array}{l}\text { Obeying the } \\
\text { commands of } \\
\text { god }\end{array}$ & 16 & 61.5 & 14 & 77.8 & 57 & 57.6 & 11 & 42.3 & 40 & 44.9 & 7 & 16.7 & 48.562 & ${ }_{<0.001}^{\mathrm{MC}_{\mathrm{p}}}$ \\
\hline & $\begin{array}{l}\text { Have the same } \\
\text { desire }\end{array}$ & 2 & 7.7 & 1 & 5.6 & 6 & 6.1 & 1 & 3.8 & 7 & 7.9 & 5 & 11.9 & & \\
\hline & All of above & 5 & 19.2 & 2 & 11.1 & 28 & 28.3 & 14 & 53.8 & 40 & 44.9 & 30 & 71.4 & & \\
\hline & Other reasons & 3 & 11.5 & 1 & 5.6 & 8 & 8.1 & 0 & .0 & 2 & 2.2 & 0 & 0.0 & & \\
\hline \multirow{5}{*}{$\begin{array}{l}\text { Method of } \\
\text { foreplay before } \\
\text { sexual } \\
\text { intercourse }\end{array}$} & No foreplay & 8 & 30.8 & 6 & 33.3 & 21 & 21.2 & 4 & 15.4 & 13 & 14.6 & 0 & 0.0 & $72.259^{*}$ & ${ }^{\mathrm{MC}} \mathrm{p}$ \\
\hline & Verbal method & 0 & 0.0 & 1 & 5.6 & 18 & 18.2 & 5 & 19.2 & 5 & 5.6 & 0 & 0.0 & & $<0.00$ \\
\hline & $\begin{array}{l}\text { Physical } \\
\text { method }\end{array}$ & 11 & 42.3 & 7 & 38.9 & 32 & 32.3 & 8 & 30.8 & 29 & 32.6 & 9 & 21.4 & & $1^{*}$ \\
\hline & $\begin{array}{l}\text { Both verbal } \\
\text { and physical } \\
\text { methods }\end{array}$ & 5 & 19.2 & 3 & 16.7 & 19 & 19.2 & 8 & 30.8 & 37 & 41.6 & 33 & 78.6 & & \\
\hline & Other & 2 & 7.7 & 1 & 5.6 & 9 & 9.1 & 1 & 3.8 & 5 & 5.6 & 0 & 0.0 & & \\
\hline \multirow{6}{*}{$\begin{array}{l}\text { Duration of } \\
\text { foreplay before } \\
\text { sexual } \\
\text { intercourse } \\
\text { Pain during } \\
\text { sexual } \\
\text { intercourse }\end{array}$} & Enough & 10 & 38.5 & 9 & 50.0 & 61 & 61.6 & 16 & 61.5 & 66 & 74.2 & 39 & 92.9 & $28.341^{*}$ & $<0.00$ \\
\hline & Not enough & 16 & 61.5 & 9 & 50.0 & 38 & 38.4 & 10 & 38.5 & 23 & 25.8 & 3 & 7.1 & & $1^{*}$ \\
\hline & Always & 10 & 38.5 & 6 & 33.3 & 25 & 25.3 & 2 & 7.7 & 3 & 3.4 & 1 & 2.4 & $63.832^{*}$ & ${ }^{\mathrm{MC}} \mathrm{p}$ \\
\hline & $>$ half times & 8 & 30.8 & 5 & 27.8 & 22 & 22.2 & 6 & 23.1 & 15 & 16.9 & 2 & 4.8 & & $<0.00$ \\
\hline & $<$ half times & 4 & 15.4 & 4 & 22.2 & 22 & 22.2 & 6 & 23.1 & 21 & 23.6 & 12 & 28.6 & & $1^{*}$ \\
\hline & $\begin{array}{l}\text { Rare or almost } \\
\text { never }\end{array}$ & 4 & 15.4 & 3 & 16.7 & 30 & 30.3 & 12 & 46.2 & 50 & 56.2 & 27 & 64.3 & & \\
\hline Active role & All the times & 1 & 3.8 & 6 & 33.3 & 37 & 37.4 & 11 & 42.3 & 29 & 32.6 & 17 & 40.5 & $39.999^{*}$ & $<0.00$ \\
\hline during & $>$ half the times & 5 & 19.2 & 5 & 27.8 & 20 & 20.2 & 9 & 34.6 & 32 & 36.0 & 17 & 40.5 & & $1^{*}$ \\
\hline intercourse or & $<$ half the times & 8 & 30.8 & 2 & 11.1 & 23 & 23.2 & 4 & 15.4 & 14 & 15.7 & 7 & 16.7 & & \\
\hline $\begin{array}{l}\text { just passive } \\
\text { performance }\end{array}$ & $\begin{array}{l}\text { Always passive } \\
\text { performance }\end{array}$ & 12 & 46.2 & 5 & 27.8 & 19 & 19.2 & 2 & 7.7 & 14 & 15.7 & 1 & 2.4 & & \\
\hline Pelvic congestion & Always & 10 & 38.5 & 6 & 33.3 & 25 & 25.3 & 2 & 7.7 & 3 & 3.4 & 1 & 2.4 & $63.832^{*}$ & ${ }^{\mathrm{MC}} \mathrm{p}$ \\
\hline symptoms as & $>$ half the times & 8 & 30.8 & 5 & 27.8 & 22 & 22.2 & 6 & 23.1 & 15 & 16.9 & 2 & 4.8 & & $<0.00$ \\
\hline backache & $<$ half the times & 4 & 15.4 & 4 & 22.2 & 22 & 22.2 & 6 & 23.1 & 21 & 23.6 & 12 & 28.6 & & $1^{*}$ \\
\hline & $\begin{array}{l}\text { Never occur at } \\
\text { all }\end{array}$ & 4 & 15.4 & 3 & 16.7 & 30 & 30.3 & 12 & 46.2 & 50 & 56.2 & 27 & 64.3 & & \\
\hline Sexual & $>\mathbf{5 0 \%}$ & 6 & 23.1 & 3 & 16.7 & 37 & 37.4 & 11 & 42.3 & 45 & 50.6 & 41 & 97.6 & $67.650^{*}$ & $<0.00$ \\
\hline satisfaction & $<\mathbf{5 0 \%}$ & 10 & 38.5 & 11 & 61.1 & 33 & 33.3 & 12 & 46.2 & 23 & 25.8 & 1 & 2.4 & & $1^{*}$ \\
\hline & Dissatisfied & 10 & 38.5 & 4 & 22.2 & 29 & 29.3 & 3 & 11.5 & 21 & 23.6 & 0 & 0.0 & & \\
\hline $\begin{array}{l}\text { The reason for } \\
\text { not accepting the }\end{array}$ & $\begin{array}{l}\text { Not choosing } \\
\text { the ideal time }\end{array}$ & 1 & 3.8 & 1 & 5.6 & 25 & 25.3 & 4 & 15.4 & 11 & 12.4 & 2 & 4.8 & $43.545^{*}$ & $\begin{array}{l}{ }^{\mathrm{MC}} \mathrm{p} \\
<0.00\end{array}$ \\
\hline husband desire to & Feel tired & 8 & 30.8 & 7 & 38.9 & 28 & 28.3 & 12 & 46.2 & 29 & 32.6 & 7 & 16.7 & & $1^{*}$ \\
\hline establish sexual & Lack of desire & 2 & 7.7 & 1 & 5.6 & 11 & 11.1 & 1 & 3.8 & 14 & 15.7 & 2 & 4.8 & & \\
\hline relationship & All of above & 11 & 42.3 & 8 & 44.4 & 30 & 30.3 & 8 & 30.8 & 28 & 31.5 & 31 & 73.8 & & \\
\hline & Other reasons & 4 & 15.4 & 1 & 5.6 & 5 & 5.1 & 1 & 3.8 & 7 & 7.9 & 0 & 0.0 & & \\
\hline
\end{tabular}


Table (3)Effect of educational level on sexual satisfaction( $(n=300)$.

\begin{tabular}{|c|c|c|c|c|c|c|c|c|c|c|c|c|c|}
\hline \multirow[t]{3}{*}{ - } & & \multicolumn{12}{|c|}{ Educational level } \\
\hline & & \multicolumn{2}{|c|}{ Illiterate } & \multicolumn{2}{|c|}{$\begin{array}{c}\text { Read } \\
\text { and } \\
\text { write }\end{array}$} & \multicolumn{2}{|c|}{$\begin{array}{l}\text { Secondary } \\
\text { education }\end{array}$} & \multicolumn{2}{|c|}{$\begin{array}{l}\text { University } \\
\text { student }\end{array}$} & \multicolumn{2}{|c|}{$\begin{array}{c}\text { University } \\
\text { degree }\end{array}$} & \multicolumn{2}{|c|}{$\begin{array}{l}\text { MSC or } \\
\text { MD }\end{array}$} \\
\hline & & $\mathbf{N}$ & $\%$ & $\mathbf{N}$ & $\%$ & $\mathbf{N}$ & $\%$ & $\mathbf{N}$ & $\%$ & $\mathbf{N}$ & $\%$ & $\mathbf{N}$ & $\%$ \\
\hline Sexual & $>\mathbf{5 0 \%}$ & 6 & 23.1 & 3 & 16.7 & 37 & 37.4 & 11 & 42.3 & 45 & 50.6 & 41 & 97.6 \\
\hline satisfaction & $<50 \%$ & 10 & 38.5 & 11 & 61.1 & 33 & 33.3 & 12 & 46.2 & 23 & 25.8 & 1 & 2.4 \\
\hline & Dissatisfied & 10 & 38.5 & 4 & 22.2 & 29 & 29.3 & 3 & 11.5 & 21 & 23.6 & 0 & 0.0 \\
\hline $\begin{array}{l}\text { Statistical } \\
\text { test }\end{array}$ & $\mathbf{X}^{2}$ Test & \multicolumn{12}{|c|}{$67.650^{*}$} \\
\hline$P$ value & & \multicolumn{12}{|c|}{$<0.001^{*}$} \\
\hline
\end{tabular}

\section{Discussion}

Female sexuality and drive result from interchange of physical and emotional wellness, social and social condition, training, and individual involvement with accomplice relationship [8, 9] revealed that instructive level and sexual fulfillment were fundamentally related, especially for ladies .

The current examination attempted to assess the effect of various instructive levels on female sexuality in an example of Egyptian wedded ladies .

In this study,most of members were living in country regions $(82.7 \%)$, this can give more data about the impact of training level and provincial culture on female sexual fulfillment. In the current examination there was a noteworthy connection among's living arrangement and sexual fulfillment as, $25.8 \%$ of rustic regions members revealed sexual disappointment, while just $5.8 \%$ of urban regions members announced sexual disappointment. These outcomes can give a thought regarding instruction and social impact on female sexual fulfillment. The aftereffects of [10] study demonstrated that FGC is broadly polished in ladies from rustic zones. These discoveries may clarify the aftereffects of our investigation which revealed that sexual disappointment was higher in members from country zones than members from urban territories, as in our examination we announced that sexual disappointment was accounted for by $24.3 \%$ of cut ladies, and $8.1 \%$ of whole ladies. This is in concurrence with [10] study, that revealed that there was a high factual connection among's FGC and sexual fulfillment. In [10] study the recurrence of sexual want was lower in cut members than the whole ones, and the high recurrence of oil (happened quite often in all seasons of sex) is lower in the genitally cut ladies than whole ones. Likewise, it was discovered that the recurrence of climax was lower in the genitally cut ladies than the whole ones and dyspareunia was higher in genitally cut ladies than the whole ones in this way, sexual fulfillment was diminished in ladies who had been presented to FGC .

In our investigation there was a measurably critical connection between's level of sexual fulfillment and working while sexual disappointment was higher in working women $(28.3 \%)$ contrasted with non-working women $(15.6 \%)$ and this concurs with [11] who detailed that housewives have a superior nature of sexual coexistence than ladies at work.
There was a high measurably critical connection $(p<0.001)$ between the members level of training in regards to thoughts regarding sexual relationship before marriage that expanded with expanding level of instruction to get $95.2 \%$ at $\mathrm{MSc}$ or MD instruction because of various wellspring of information web $(35.7 \%)$, books $(33.3 \%)$, family $(16.7 \%)$ and companions $(9.5 \%)$ while unskilled ladies had just two sources family(34.6\%) and friends $(7.7 \%)$,so the assessment of sexual information before marriage was right in $\mathrm{MSc}$ or $\mathrm{MD}(85.7 \%)$ and half erroneous in uneducated ladies. Elevated level of instruction women(MSc or MD) can manage any issue identified with sexuality $(85.7 \%)$ and this concurs with [12] who found that the higher the instructive level, the better the sexual encounters. What's more, concurs with [13] who found that expanding ladies' data about sex prompts an adjustment in their mentalities toward sexual movement, and concurs with [14] who found that expanding information and improving the demeanor of ladies builds the sexual fulfillment of ladies .

In the current examination, information about explicitly transmitted contaminations was found in all members of significant level of instruction $(100 \%$ in MSC or MD)while $84.6 \%$ of uneducated ladies knew nothing about explicitly transmitted diseases. This is in concurrence with [15] who revealed that exceptionally taught ladies despite everything experience more significant levels of explicitly transmitted diseases (STI) data than less instructed ladies .

In our investigation there was a high factually critical relationship $(\mathrm{p}<0.001)$ between the six degrees of instruction in regards to coital recurrence; the commonest coital recurrence was 2-3 times each week in members yet the rate was higher in MSc or MD ladies (69.0\%) contrasted with uneducated people $(42.3 \%)$ and this concurs with [16] who found that coital recurrence increments with exceptionally taught ladies .

The current examination demonstrated that expansion in level of training prompts expanded sexual action (want, grease, sexual satisfaction), the commonest revealed unconstrained want (when seven days) in the six degrees of instruction was in MSC or MD members (35.7\%) contrasted with uneducated people $(23.1 \%)$, oil happened quite often in all seasons of sex in MSC or MD members $(69.0 \%)$ and detailed once in a while or never happen in unskilled people $(42.3 \%)$ and this concurs with [17] who announced that there was a critical relationship between 
instructive level and sexual working (want, oil, climax and fulfillment .(

Foreplay length was sufficient to accomplish energy in three more elevated levels of training [MSc or MD $(92.9 \%)$, college degree $(74.2 \%)$ and college understudies $(61.5 \%)]$ while it was insufficient in three low degrees of instruction [illiterate $(61.5 \%)$, peruse and compose $(50.0 \%)$ and auxiliary instruction $(38.4 \%)$ ]and this concurs with [18] who found that among school taught people, foreplay would in general be considerably more broadened, by and large going somewhere in the range of five and fifteen minutes. Those with advanced education were unquestionably bound to consistently use an assortment a sexual methods, including manual incitement of the private parts, profound kissing, and bosom incitement .

In the current examination dyspareunia was once in a while or never happened in three elevated levels of training [MSc or MD (64.3\%), college degree $(56.2 \%)$ and college understudies (46.2\%)] while it generally happened with three low degrees of instruction [illiterates $(38.5 \%)$, peruse and compose (33.3\%) and optional instruction (25.3\%)] and this concurs with [19] who revealed that training demonstrated huge connection to dyspareunia, ladies with secondary school or college level instruction had less encounters of dyspareunia contrasted and low taught ladies and this was clarified by [20] who announced that ladies with higher instructions would confront sexual brokenness less frequently. Indeed, higher instructive fulfillments increment the possibility that people can talk about their sexual issues or their life partners. Preparing and high instructive achievements are important to have alluring and typical sexual exercises [21].

In the current examination sexual fulfillment over half was more in three elevated levels of instruction [MSc or MD (97.6\%) , college degree $(50.6 \%)$ and college understudy (42.3\%)] while sexual fulfillment under half was accounted for additional in three low degrees of training [illiterate $(38.5 \%)$, peruse and compose $(61.1 \%)$ and auxiliary training (33.3\%)] and this concurs with [22] who revealed that the connection among instruction and sexual fulfillment demonstrated that ladies with advanced education express increasingly sexual fulfillment. This finding could be because of the expansion of people's information which thus changes individual's disposition toward sex and sexual fulfillment .

\section{Conclusion}

Educational level and sexual satisfaction were significantly associated.

Working as well as female genital cutting have a negative impact on female sexual satisfaction.

Sexual knowledge and experience increases with increasing level of education. Women with high level of education can deal with any problem related to sexuality so female sexual dysfunctions are less in highly educated women.

Increase in the level of education leads to increase sexual activity (desire, lubrication, sexual satisfaction) and to more sexual satisfaction.

\section{References}

[1] R. Rosen, C. Brown, J. Heiman, The female sexual function index (FSFI): A multidimensional selfreport instrument for the assessment of female sexual function. J Sex Marital Ther, Vol. 26(2), PP. 1920,2000.

[2] S. Bridges, S. Lease, C. Ellison Predicting sexual satisfaction in women: Implication for counselor education and training. J CounsDev, Vol. 82, PP. $158-166,2004$

[3] P.M. Pascoal, I.D.S.B. Narciso, N.M. Pereira, What is sexual satisfaction?thematic analysis of lay people's definitions. J Sex Res, Vol.51(1), PP.22-30 ,2014.

[4] S. Ventegodt, Sex and the quality of life in Denmark. Arch Sex Behav, Vol.27(3), PP.295-307, 1998.

[5] I.C. Anochie , E.E. Ikpeme , Prevalence of sexual activity and outcome among female secondary school students in Port Harcourt, Nigeria. Afr J Reprod Health, Vol.5, PP.63-67, 2001.

[6] M. Young, G. Denny, R. Luquis , Correlates of sexual satisfaction in marriage. Can J Hum Sex, Vol.7(2), PP. 115-127, 1998.

[7] M.E. Greene, Z. Rasekh, K. Amen, Sexual and Reproductive Health Policies for a Youthful World. Population Action International.Washington, , Vol. 60, PP. 168 -179, 2002.

[8] D.R. Ambler, E.J. Bieber, M.P. Diamon , Sexual function in elderly women. A review of current literature.Rev ObstetGynecol, Vol.5, PP.16-27, 2012.

[9] J.E. Barrientos ,D.Paez , Psychosocial Variables of Sexual Satisfaction in Chile. J Sex Marital Ther,Vol. 32, PP.351-368, 2006.

[10] M. Abdou , A comparative study between sexuality of genitally cut and uncut women. M. Sc .Thesis, Benha University, Vol. 40, PP.420-435, 2018.

[11] M. Charandabi, M. Mirghafourvand, M. AsghariJafarabadi, Modeling of socio-demographic predictors of sexual function in women of reproductive age. J Mazandaran University of Medical Sci, Vol. 23(110), PP.237-242, 2014.

[12]L.I. Chunyan, W.U. Taiwen, L. I. Lihe, The relationships of school-based sexuality education, sexual knowledge and sexual behaviors - a study of 18,000 Chinese college students. Reproductive Health,Vol. 14, PP.103, 2017.

[13] M. Sasanpour, A. Azizi , M. Dehghan , The Effectiveness of Sexual Cognitive Restructuring on Marital Satisfaction and Mental Health of the Couples in Esfahan. J Community Health, Vol.10, PP. 1-10, 2016.

[14] F. Soltani, R. Azizi, H. Sourinegad, Sexual knowledge and attitude as predictors of female sexual satisfaction. Biomed Res Ther,Vol. 4(12), pp.1874-1884, 2017.

[15]L. Annang, K.M. Walsemann, D. Maitra , Does education matter? examining racial differences in the association between education and STI diagnosis among black and white young adult females in the 
U.S. Public Health Rep,Vol.125(4), PP. 110-121, 2010.

[16]H. Stewart, L. Morison R. White, Determination of coital frequency among married women in central African republic: the role of female genital cutting. J Cambridge University, Vol.4(34), PP.525-539, 2002.

[17] E. Tammary, K. Samuel, N. Isaac, The 'heat' goes away: sexual disorders of married women with female genital mutilation/cutting in Kenya. J ReprodHealth,Vol .164, PP. 320-350, 2017.

[18] S. Samuel , L. Cynthia The Janus Report on Sexual Behavior. New York: John Wiley \& Sons, Vol. 25(5) , PP.255-280,1993.

[19]S. Sobhgol , S . Mohammad , Rate and related factors of dyspareunia in reproductive age women: a cross-sectional study. Int J Impot Res, Vol.19, PP. 88-94, 2017.

[20] B.A. Fajewonyomi, E.O. Orji , A.O. Adeyemo , Sexual dysfunction among female patients of reproductive age in a hospital setting in Nigeria. $\mathbf{J}$ Health PopulNutr,Vol. 25(1), PP.101-106, 2007.

[21]M. Ramezani, M. Dolatian, J .Shams , The relationship between self-esteem and sexual dysfunction and satisfaction in women. J Arak Univ Med Sci, Vol.14(6), 57-65,2012.

[22] H. De Graaf, I .Vanwesenbeeck , S .Meijer Educational Differences in adolescents' sexual health: a pervasive phenomenon in a national Dutch sample. J Sex Res, Vol.25(6), pp.1-1,12014. 